\title{
CDC7 Kinase Inhibitor NMS-1116354
}

National Cancer Institute

\section{Source}

National Cancer Institute. CDC7 Kinase Inhibitor NMS-1116354. NCI Thesaurus. Code C88316.

An orally bioavailable cell division cycle 7 homolog (CDC7) kinase inhibitor with potential antineoplastic activity. CDC7 kinase inhibitor NMS-1116354 binds to and inhibits the activity of $C D C 7$, which may result in the inhibition of DNA replication and mitosis, the induction of tumor cell apoptosis, and the inhibition of tumor cell proliferation in CDC7overexpressing tumor cells. The serine-threonine kinase CDC7 initiates DNA replication by phosphorylating MCM2 (minichromosome maintenance complex component 2) at Ser40 and Ser53. 